\title{
Recovery room
}

\section{problems or problems in the PACU}

\section{Objectives}

This lecture will cover four areas: First, the early history of the PACU will be briefly discussed so that the reasons for the need and the development of a Post Anaesthetic Care Unit can be better understood. Second, the current guidelines and suggestions for the administration and care of patients in the PACU will be appraised. The third focus will be a review of epidemiological studies which have identified the commonest PACU problems. Specific strategies for prevention and treatment of common problems will be outlined. Since it is unlikely that current PACUs will escape costcutting strategies, the lecture will close with a brief discussion of future trends and potential changes in the organization and management of the PACU.

\section{History: why do we have the PACU?}

The concept of the recovery room was not always a part of the hospital. The first recorded description of a recovery room. was at Newcastle Infirmary in 1801, but it took over 70 years for a recovery ward to be established in the United States at the Massachusetts General Hospital. ${ }^{1}$

It was not until after the second world war that recovery rooms were routinely included in plans for new hospitals. ${ }^{2}$ Recovery rooms were provided so that patients could regain consciousness in relative safety and restore body warmth. They also protected other ward occupants from the distressing sound and sight of postoperative vomiting! But the more crucial need for a recovery room was recognized in an article which appeared in a 1947 issue of the Journal of the American Medical Association. ${ }^{3}$ Perioperative deaths associated with respiratory obstruction were described and the need for postanaesthesia rooms was strongly emphasized.

Even as late as 1982, a survey by Tiret found major complications occurring with anaesthetic management in about $1 / 700$ cases, and of those cases that resulted in death or coma, approximately half of them were associated with postanaesthetic respiratory depression. ${ }^{4}$ When postoperative respiratory depression did occur, it was fatal in $70 \%$ of cases when it occurred on the ward versus $29 \%$ when it occurred in the operating theatre, recovery room, or intensive care unit. The authors con-

\section{Keith Rose MD FRCPC}

cluded that the prognosis of patients was directly related to the availability of a postanaesthetic recovery room.

Recovery room function is always changing. Critical care units with facilities for postoperative mechanical ventilation are often inadequate necessitating the use of the PACU for complex surgical patients who require short-term intensive care. On the other hand, the trend toward outpatient surgery broadens the scope of PACU care to include management of patients who will subsequently be discharged home. PACU case mix continues to be dependent upon individual hospital objectives.

\section{Current standards}

Canadian Anaesthetists Society Guidelines, updated in 1995, have included a section which deals specifically with the postanaesthetic period. ${ }^{5}$ These guidelines indicate, "In any hospital providing anaesthetic services, a postanaesthetic recovery (PAR) room must be available." The recommendations also state that the Department of Anaesthesia shall have overall medical administrative responsibilities of this area and indicate that "Care should not be delegated to the PAR room nurse until the anaesthetist is assured that the patient may be safely observed and cared for by the nursing staff."

Patients may be discharged from the PACU by an anaesthetist, or this act may be a delegated responsibility in accordance with hospital policy. The guidelines also stipulate the necessary resuscitation and life support equipment, oxygen, suction, monitoring devices, and pulse oximetry for the initial phase of recovery which should be available in the PACU. The guidelines indicate that appropriate records, including complications, be charted for each patient. The Canadian regulations regarding the routine use of pulse oximetry became mandatory on July 1, 1995.

Similar guidelines were approved by the American Society of Anesthesiologists in $1994 .{ }^{6}$ In addition, the American guidelines encourage the use of a PACU scoring system for each patient on admission and at appro-

From the Department of Anaesthesia, St. Michael's Hospital, 30 Bond Street, Toronto, Ontario M5B 1W8. 
priate intervals until the time of discharge. ${ }^{7}$ They also stipulate that a physician capable of managing complications and providing cardiopulmonary resuscitation for patients in PACU must be available.

\section{Why are PACU problems important?}

In the argument around what are "true" anaesthetic outcomes, some have suggested that events in the PACU tend to be "intermediate" and not "true" endpoints. Investigators have recently suggested that not only is it necessary to recognize early events (e.g., PACU problems), but it is also imperative to identify those which impact on long-term morbidity and hospital costs. ${ }^{8,9}$ Studies of infrequent but severe respiratory problems which occur in the PACU suggest that these problems are associated with increased postoperative morbidity. However, recognition of more frequently occurring events (e.g., hypoxaemia detected by pulse oximetry) failed to reduce major postoperative complications. ${ }^{10}$

On the other hand, when excessive pain was documented in the PACU, patients were more likely to experience increased pain after leaving PACU. ${ }^{11}$ As well, nausea and vomiting has been associated with increased length of stay in recovery room and increased rate of unplanned admission to hospital. These outcomes are associated with increasing costs to the hospital sector. When considering the impact of PACU events on long-term morbidity, assessment of PACU care may require additional indicators (e.g., patient satisfaction and time needed to return to routine daily living pattern).

\section{Type and frequency of complications occurring in the PACU}

Despite advances in monitoring and anaesthetic management, several patient surveys report that a high incidence of problems occurs in the PACU (Table I). These studies illustrate that the rate of PACU events depends on which adverse events are included in the study and what definitions of events are used.

At St. Michaels Hospital, Toronto we have studied common problems in the PACU using much more rigorous definitions of PACU events, by considering variation from normal physiological limits and by specific interventions (Figure). Between 1991 and 1994, 43,914 consecutive patients have been admitted to the PACU. Thirty-three percent of these patients had some kind of problem in the PACU, the most common being nausea and vomiting, haemoglobin oxygen desaturation, excessive pain, confusion/agitation, bradycardia, hypotension, and hypertension.

Several problems in PACU will be reviewed with specific emphasis on their frequency, aetiology, preven-
TABLE I Frequency of PACU problems

- Critical incidents in PACU (1986 - USA $)^{46}-7 \%$

- Anaesthetic related RR complications (1985 - Australia $)^{47}-30 \%$

- Serious RR complications ( $1975-83$ Canada ${ }^{48}-5 \%$

- Survey of PACU complications (1986 - 89 USA $)^{49}-24 \%$

- Major incidents related to anaesthesia (1987- 92 AIMS-Australia) ${ }^{50}$ (6\% occurred in PACU)

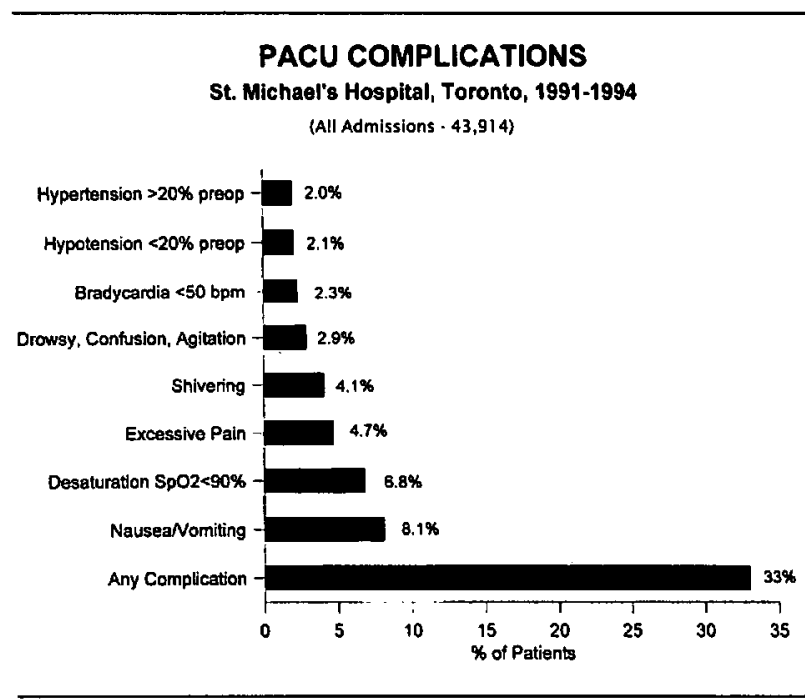

FIGURE

TABLE II Patient and surgical factors which increase risk of nausea and vomiting

- Female sex

- Younger age

- Previous history of perioperative nausea and vomiting

- Nonsmokers

- Abdominal, laparoscopic, and strabismus procedures

- Postoperative opioid use

tion, and treatment. These remarks apply to surgical patients who are routinely admitted to the PACU.

\section{Nausea and vomiting}

Despite decades of research, nausea and vomiting remains the most common problem observed in the PACU. This may represent only the tip of the iceberg since the rate of nausea/vomiting is thought to be even higher in the later postoperative period. Various factors associated with a higher frequency of nausea and vomiting are noted in Table II. ${ }^{12}$

Several randomized controlled trials have examined various therapies to prevent nausea and vomiting. The newer drug, propofol used as an induction agent with a continuous infusion for maintenance of anaesthesia has 
TABLE III Factors which increase risk of respiratory problems PACU

- Obesity

- Older age

- Abdominal surgery

- Emergency procedure

- Long duration of operative procedure

- Pre- and intraoperative opioid use

- Neuromusclar relaxants

- Airway obstruction during emergence from anaesthesia

been shown to reduce the frequency of nausea and vomiting in outpatients. ${ }^{13}$ Droperidol at several dosage ranges has been shown to reduce the incidence of nausea and vomiting, but results for the short-acting agent metoclopramide have not been conclusive. ${ }^{14}$ The newer and considerably more expensive antiserotonin drugs have shown results as good as or better than those studies which used droperidol. ${ }^{15}$ The antiserotonin agents appear to have minimal side effects but we have found few adverse reactions with the use of droperidol at our hospital (Cohen, Rose and Yee in press).

Despite routine use for several years, the effectiveness of rescue antiemetics has been poorly studied. Commonly used therapies with varying rates of effectiveness include antihistamines (dimenhydrinate Gravol ${ }^{\circledR}$ and diphenhydramine - Benadryl ${ }^{\circledR}$ ), phenothiazines (perphenazine - Trilafon ${ }^{\circledR}$ and prochlorperazine - Stemetil ${ }^{\circledR}$ ), benzamides (metoclopramide - Maxeran $\left.{ }^{\circledR}\right)$, butyrohenones (droperidol - Inapsine ${ }^{\circledR}$ ), and alpha stimulators (ephedrine).

Unfortunately, even studies of either prophylactic or therapeutic agents which demonstrate reduced incidence of nausea and vomiting compared with that of placebo rarely show more than a relative reduction of $50 \%$ in the incidence of nausea and vomiting. Postoperative nausea and vomiting remains the "little problem that refuses to go away" and is a common source of patient dissatisfaction and delay in recovery room discharge.

\section{Respiratory problems}

Respiratory complications in the postanaesthesia period are an important area of concern for anaesthetists. Fortunately, the frequency of serious respiratory problems is low. In Beard's 1981 study, respiratory complications comprised 44 out of 2,293 (1.9\%) cases of general anaesthesia. ${ }^{16}$

Our study carried out ten years later at St. Michaels Hospital, Toronto determined that critical respiratory events occurred in $1.3 \%$ of 24,157 consecutive PACU patients receiving general anaesthesia. ${ }^{17}$ Over two thirds of these respiratory events were associated with haemo- globin desaturation $<90 \%$. Interventions used to treat critical respiratory events included insertion of oral/ nasal airways $(\mathbf{5 9 . 7 \% )}$ ) and airway manipulation $(47.6 \%)$. Only 22 patients $(0.1 \%)$ required emergency tracheal intubation in the PACU.

Patient and surgical factors and specific anaesthetic management strategies may increase the risk of respiratory problems in the PACU (Table III). Respiratory events in order of decreasing frequency which have been noted in the PACU include hypoxemia, hypoventilation, airway obstruction, bronchospasm, laryngospasm, aspiration, and pneumothorax.

Hypoxaemic episodes $\left(\mathrm{SpO}_{2} \leq 90 \%\right)$ have been recorded in up to $55 \%$ of patients admitted to a PACU. ${ }^{18}$ Many of these patients were receiving supplemental oxygen, and $95 \%$ of the cases went unrecognized by the staff. The aetiology of hypoxaemia in the PACU is most commonly due to $\mathrm{V} / \mathrm{Q}$ mismatch and is frequently seen in patients with compromised lung function in the preoperative period (e.g., low preoperative $\mathrm{SpO}_{2}$ ).

Hypoventilation in the PACU is recognized by low respiratory rate or rapid shallow pattern of respiration. Interference with the central respiratory drive (a low respiratory rate) has been associated with opioid use. ${ }^{19}$ A narcotic antagonist can easily reverse opioid-induced hypoventilation, but the duration of action may be shorter than that of the opioid which caused the problem. When considering the aetiology of both hypoxaemia and hypoventilation in the PACU, it is important to note that decreased level of consciousness on arrival in PACU has been cited as an important risk factor. ${ }^{20}$ Initially, the signs and symptoms of hypoxaemia and hypoventilation may not be obvious to the clinician. Airway obstruction secondary to depressed level of consciousness, residual effects of neuromuscular blocking agent, and surgical bleeding compromising the airway demands early recognition.

Aspiration pneumonitis is extremely uncommon. A recent review identified 67 cases out of 215,488 general anaesthetics. $^{21}$ Fortunately, $64 \%$ of these patients did not have clinical, laboratory, or $x$-ray abnormalities, and none of these patients without symptoms developed late respiratory sequelae. The authors suggested that if patients with clinically apparent aspiration do not develop symptoms within two hours of surgery, they are unlikely to have further respiratory sequelae.

Pneumothorax may be related to the surgical procedure (upper abdominal, nephrectomy, and percutaneous nephrostomy). Current guidelines suggest that patients who will subsequently require mechanical ventilation should have a chest tube, while only those who are symptomatic or have $>20 \%$ pneumothorax with spontaneous respiration will benefit from a chest tube. 
Preventative strategies to avoid PACU respiratory problems include early identification of the patient at high risk and planned postoperative mechanical ventilation, avoidance of long-lasting anaesthetic drugs which depress level of consciousness, relief of pain during the early postoperative period, and close monitoring for all patients following general anaesthesia in the PACU where personnel are readily available to intervene.

\section{Pain}

While all patients will have pain after major surgery, the degree to which excessive pain is experienced will vary considerably. This makes the prevention and treatment of pain challenging, but also difficult to study. Postoperative pain in the PACU is currently being assessed by several methods. These include visual analogue pain scores ( 0 - no pain, maximum - worst pain imaginable) measured at rest and with movement, discomfort scores which rate level of pain (no pain, mild, moderate, severe, or very severe), frequency of demand for and quantity of opioid analgesics, and physical findings related to severe pain (e.g., moaning or writhing). Due to patient sedation and confusion, pain assessment in the PACU may not be reliable. Many of the recent studies which assess strategies to reduce postoperative pain ignore the patient stay. in PACU and instead concentrate on time periods after PACU discharge.

However, one study of patients undergoing abdominal surgery did measure analogue pain scores on arrival in PACU. ${ }^{22}$ Pain scores $(0-10)$ were high $(>6)$ and dependent on intraoperative management. Our own findings in the PACU at St. Michaels Hospital, Toronto also suggested a high frequency of early postoperative pain. ${ }^{23}$ This study which assessed over 5,000 high-risk patients in the PACU (elective major surgery following general anaesthesia) found that the rate of excessive pain, defined by moaning or writhing or nursing care dominated by pain control, was $14.8 \%$. The rate of excessive pain in the PACU may vary depending on patient age, preoperative analgesic use, the surgical procedure, and strategies to reduce postoperative pain (Table IV).

A newer development in postoperative pain management has been the use of NSAIDs and local anaesthetics, but their effectiveness in day-to-day practice is unclear. Oral naproxen compared with placebo in healthy outpatients who had either arthroscopic knee surgery or laparoscopic tubal ligations reduced visual analogue pain scores at one and two hours. ${ }^{24,25}$ As well, indomethacin decreased visual analogue scores measured at 15 and 60 min after arrival in PACU in healthy women undergoing breast surgery and gynaecological procedures. ${ }^{26}$ However, ketorolac given intraoperatively
TABLE IV Strategies to reduce early postoperative

\begin{tabular}{ll}
\hline NSAIDs & $\begin{array}{l}\text { Preoperative, intraoperative } \\
\text { Wocal anaesthetics }\end{array}$ \\
& $\begin{array}{l}\text { Wound infiltration } \\
\text { Joint instillation } \\
\text { Nerve block }\end{array}$ \\
& $\begin{array}{l}\text { Epidural/intrathecal } \\
\text { Intravenous (short versus long-acting) }\end{array}$ \\
Opioids & Epiduralintrathecal \\
Multimodal & \\
Preemptive timing & \\
\hline
\end{tabular}

to women undergoing a different procedure, abdominal hysterectomy, did not reduce the opioid consumption in the PACU compared to a placebo group. ${ }^{27}$ The expense of ketorolac and the rectal administration of indomethacin has limited the use of NSAIDs in every day practice.

Studies of local anaesthetics have shown them to be effective in reducing early postoperative pain but their adoption in clinical practice has been slow. Compared with a placebo group, patients who underwent abdominal surgery and had an infiltration of bupivacaine in the operative site had reduced visual analogue pain scores on arrival in PACU and required less morphine. ${ }^{22}$ Intra-articular bupivacaine reduced mean visual analogue scores at one and two hours post surgery compared with intra-articular morphine and also reduced the time to first opioid requirement. ${ }^{28}$ Although the longterm benefits of epidurals with opioids and/or local anaesthetics are controversial, Jayr et al. demonstrated that a mixture of bupivacaine and morphine infused continuously into the epidural space dramatically reduced visual analogue pain scores a rest in the PACU compared with morphine injected subcutaneously. ${ }^{29}$ Other studies have suggested multimodal approaches or preemptive techniques such that several therapies each acting at different sites before the onset of pain are used to reduce postoperative pain.

Intravenous or intramuscular morphine has been the primary treatment of early postoperative pain. Patientcontrolled analgesia systems, started in the PACU following nurse initiated opioid loading, have been shown to improve patient satisfaction and reduce pain in the later postoperative period. ${ }^{30}$ Whether PCA is superior to other methods of pain control remains to be determined. The benefits of the shorter-acting analgesics (fentanyl and alfentanil) and the newer nonsteroidals for treatment of acute pain have not been fully studied. Oral analgesics may be suitable for some patients following outpatient procedures. Hospitals and patients have been quick to adopt PCA but some of the other newer modalities have not gained universal acceptance. 
Drowsiness, confusion, and agitation

These problems represent a continuum of CNS depression which is often difficult to define and quantify in the PACU. Agitated patients require constant care from PACU nurses. With the increasing number of surgical procedures performed for the elderly, this problem may be noted with increasing frequency. Aetiological factors noted in recent review articles are summarized in Table V. ${ }^{31-34}$

For the treatment of acute delirium in the recovery room, Haloperidol $0.5-5 \mathrm{mg} i v$ is probably the best choice, although few randomized studies have been reported ${ }^{35}$ Midazolam and propofol may also be useful for short-term therapy.

\section{Cardiac abnormalities}

Acute changes in blood pressure, heart rate and rhythm are not uncommon events among patients in the PACU. Ischaemia, pulmonary oedema, and cardiac arrest, on the other hand, are rare events. Preoperative patient problems (coronary artery disease, hypertension, and congestive failure) as well as surgical factors (vascular surgery, lengthy and emergency procedures) are highly correlated with early postoperative cardiac abnormalities. ${ }^{36}$ In addition, it has also been shown that other problems which occur in the PACU (e.g., respiratory distress, excessive pain, agitation, and nausea and vomiting) are related to cardiac events in the PACU. ${ }^{37}$ Recognizing the patient at risk, careful intraoperative haemodynamic control with volume replacement and drug therapy, and prevention of other system problems may help avoid cardiovascular instability in the PACU. Certain events (e.g., bradycardia) may require no treatment.

Two less common problems in the PACU, ischaemia and pulmonary oedema, will be reviewed in more detail. The diagnosis of postoperative myocardial ischaemia depends on the monitors used for detection. No single sensitive and specific test to detect myocardial ischaemia is currently available. Indicators, in order of decreasing sensitivity, include segmental wall abnormalities diagnosed by transoesophageal or thoracic echocardiography, enzyme changes, continuous ST-segment monitoring, intermittent recording of 12-lead ECGs, and patient complaints of chest pain. ${ }^{38} \mathrm{~T}$-wave changes have been shown to occur in up to $20 \%$ of patients when measured one hour after operation but frequency did not differ in those with and without coronary artery disease suggesting that $\mathrm{T}$-wave changes are a poor diagnostic tool. ${ }^{39}$ Holter monitoring (2-lead) also had poor sensitivity in detecting early postoperative ischaemia compared with serial 12-lead ECGs and CKMB assays. ${ }^{40}$ In this same study, even when myocardial ischaemia was
TABLE V Aetiology of dro'

- Advanced age

- Preoperative confusion/disor

- History of alcohol abuse

- Intraoperative anticholinergi

- Hypoxaemia

- Bladder distention

- Acute pain

- Hypovolaemia

- Electrolyte disturbances

detected by ST-segment of chest pain. At best, w operative data which : myocardial ischaemia it risk may improve the cli patients who may have : dial ischaemic episode more aggressive monito the preoperative period, events are clinically siles

Pulmonary oedema ir is rarely due to fluid ovi has severely compromis who are over infused wi and TURP). Early pos may also occur followi The aetiology of this noI may be related to neg which results in the tr monary capillaries into been suggested that thi: the relief of the negative PEEP-like effect due to tion disappears, and tt exceeds the capacity of $c$ latter theory would exp type of noncardiogenic . of the airway obstructir obstruction and sympi PEEP) corrects noncardi

New problems and cha In this era of fiscal res anaesthesia has not been tal care is being evalua the PACU has also come

The cost of running : personnel salaries and $\mathrm{m}$ unpublished data). It has delivery with shorter-ac vent or avoid common 
and vomiting) will effectively reduce PACU costs by decreasing length of PACU stay.

However, a recent hypothetical analysis by Dexter $e t$ $a l$. suggested that changing operating room schedules to optimize admission rates would do more to reduce the number of nurses than other efforts to reduce length of stay in the PACU. ${ }^{42}$ A second study by Dexter et al. was a theoretical exercise of cost savings which could occur by eliminating severe adverse anaesthetic outcomes. ${ }^{43} \mathrm{~A}$ $0.5 \%$ cost savings following kidney transplantation and $1.8 \%$ cost savings following total hip replacement would hypothetically occur. In this study, the authors computed the percentage decrease in total cost by reducing the cost of those with adverse outcomes to the median level. This article suggested that it may be difficult to prove that strategies which reduce adverse outcomes following anaesthesia are cost effective.

Traditional approachestin PACU may need to be reexamined. Two recent articles suggested that oxygen therapy in the PACU can be eliminated in some patients. ${ }^{44,45}$ The PACUs which rely on discharge time related to duration of anaesthesia or procedure-specific times should re-examine these protocols. Discharge readiness scores similar to those already instituted in the surgical step-down areas may reduce duration of PACU stay. Future studies may help identify which patients actually require or benefit from PACU care and others who could, with little increased risk, bypass their stay in the PACU. Perhaps it is no longer necessary for all patients to be admitted to a PACU. Criteria for recovery room utilization has come full circle from the historical picture outlined at the beginning of this review.

Future anaesthesia research must help identify effective strategies which are patient-focussed (i.e., reduce problems and increase patient satisfaction) and result in overall cost savings during the perioperative and PACU period.

\section{References}

$1 Z u c k D$. Anaesthetic and postoperative recovery rooms. Some notes on their early history. Anaesthesia 1995; 50: 435-8.

2 Feeley TW. The postanesthesia care unit. In: Miller RD (Ed.). Anesthesia. 3rd ed. New York: Churchill Livingstone. 1990: 2113-33.

3 Ruth HS, Haugen FP, Grove DD. Anesthesia study commission. Findings of eleven years activity. JAMA 1947; 135: 881-4.

4 Tiret L, Desmonts J, Hatton F, Vourch G. Complications associated with anaesthesia - a prospective survey in France. Can J Anaesth 1986; 33: 336-44.

5 Guidelines to the Practice of Anaesthesia. Canadian Anaesthetists Society, 1995
6 ASA Standards, Guidelines and Statements. American Society of Anesthesiologists, 1994

7 Aldrete JA, Kroulik D. A postanesthetic recovery score. Anesth Analg 1970; 49: 924-33.

8 Fisher DM. Surrogate end points. Are they meaningful? (Editorial). Anesthesiology 1994; 81: 795-6.

9 Orkin FK, Cohen MM, Duncan PG. The quest for meaningful outcomes (Editorial). Anesthesiology 1993; 78: 417-22.

10 Moller IT, Johannessen NW, Espersen K, et al. Randomized evaluation of pulse oximetry in 20,802 patients: II. Perioperative events and postoperative complications. Anesthesiology 1993; 78: 445-53.

11 Rose $K$, Cohen $M$, Yee $D$. Preventing early postoperative pain: what makes the difference? Anesthesiology 1995; 83: A1099

12 Watcha MF, White PF. Postoperative nausea and vomiting. Its etiology, treatment, and prevention. Anesthesiology 1992; 77: 162-84.

13 Doze VA, Shafer A, White PF. Propofol-nitrous oxide versus thiopental-isoflurane-nitrous oxide for general anesthesia. Anesthesiology 1988; 69: 63-71.

14 Lin D, Furst SR, Rodarte A. A double blinded comparison of metochlopramide and droperidol for prevention of emesis following strabismus surgery. Anesthesiology 1992; 76: 357-61.

15 Paxton LD, McKay AC, Mirakhur RK. Prevention of nausea and vomiting after day case gynaecological laparoscopy. A comparison of ondansetron, droperidol, metaclopromide and placebo. Anaesthesia 1995; 50: 403-6.

16 Beard $K$, Jick $H$, Walker $A M$. Adverse respiratory events occurring in the recovery room after general anesthesia. Anesthesiology 1986; 64: 269-72.

17 Rose DK, Cohen MM, Wigglesworth DF, DeBoer DP. Critical respiratory events in the postanesthesia care unit. Patient, surgical, and anesthetic factors. Anesthesiology 1994; 81: 410-8.

18 Moller JT, Wittrup M, Johansen SH. Hypoxemia in the postanesthesia care unit: an observer study. Anesthesiology 1990; 73: 890-5.

19 Goldberg ME, Torjman M, Bartkowski RR, Mora CT, Boerner T, Seltzer JL. Time-course of respiratory depression after an alfentanil infusion-based anesthetic. Anesth Analg 1992; 75: 965-71.

20 Parr SM, Robinson BJ, Glover PW, Galletly DC. Level of consciousness on arrival in the recovery room and the development of early respiratory morbidity. Anaesth Intensive Care 1991; 19: 369-72.

21 Warner MA, Warner ME, Weber JG. Clinical significance of pulmonary aspiration during the perioperative period. Anesthesiology 1993; 78: 56-62.

22 Partridge BL, Stabile BE. The effects of incisional bupivacaine on postoperative narcotic requirements, oxygen 
saturation and length of stay in the post-anesthesia care unit. Acta Anaesthesiol Scand 1990; 34: 486-91.

23 Rose DK, Cohen MM, Yee DA. Can anaesthetists change their practice to reduce postoperative pain? Can J Anaesth 1994; 41: A39.

24 Code WE, Yip RW, Rooney ME, Browne PM, Hertz T. Preoperative naproxen sodium reduces postoperative pain following arthroscopic knee surgery. Can J Anaesth 1994; 41: 98-101.

25 Comfort VK, Code WE, Rooney ME, Yip RW. Naproxen premedication reduces postoperative tubal ligation pain. Can J Anaesth 1992; 39: 349-52.

26 Morley-Forster P, Newton PT, Cook M. Ketorolac and indomethacin are equally efficacious for the relief of minor postoperative pain. Can J Anaesth 1993; 40: 1126-30.

27 Parker RK, Holtmann B, Smith I, White PF. Use of ketorolac after lower abdominal surgery. Effect on analgesic requirement and surgical outcome. Anesthesiology 1994; 80: 6-12.

28 Raja SN, Dickstein RE, Johnson CA. Comparison of postoperative analgesic effects of intraarticular bupivacaine and morphine following arthroscopic knee surgery. Anesthesiology 1992; 77: 1143-7.

29 Jayr C, Thomas H, Rey A, Farhat F, Lasser P, Bourgain $J H$. Postoperative pulmonary complications. Epidural analgesia using bupivacaine and opioids versus parenteral opioids. Anesthesiology 1993; 78: 666-76.

30 Wasylak TJ, Abbott FV, English MJ, Jeans M-E. Reduction of postoperative morbidity following patient-controlled morphine. Can J Anaesth 1990; 37: 726-31.

31 Parikh SS, Chung F. Postoperative delirium in the elderly. Anesth Analg 1995; 80: 1223-32.

32 Sheref SE. Pattern of CNS recovery following reversal of neuromuscular blockade. Comparison of atropine and glycopyrrolate. Br J Anaesth 1985; 57: 188-91.

33 Berggren D, Gustafson Y, Eriksson B, et al. Postoperative confusion after anesthesia in elderly patients with femoral neck fractures. Anesth Analg 1987; 66: 497-504.

34 Korttila K, Ostman P, Faure E, et al. Randomized comparison of recovery after propofol-nitrous oxide versus thiopentone-isoflurane-nitrous oxide anaesthesia in patients undergoing ambulatory surgery. Acta Anaesthesiol Scand 1990; 34: 400-3.

35 Tesar GE, Stern TA. Rapid tranquilization of the agitated intensive care unit. Journal of Intensive Care Medicine 1988; 3: 195-201.

36 Goldman L. Cardiac risk in noncardiac surgery: an update. Anesth Analg 1995; 80: 810-20.

37 Rose. DK, Cohen MM, DeBoer D. Does anaesthetic management contribute to hypertension and tachycardia in the post anaesthetic care unit? Can J Anaesth 1994; 41: A25.
38 Edwards ND, Reilly CS. Detection of perioperati myocardial ischaemia. Br J Anaesth 1994; 72: 10

39 Breslow MJ, Miller CF, Parker SD, Walman AT, . $M C$. Changes in T-wave morphology following a and surgery: a common recovery- room phenome: Anesthesiology 1986; 64: 398-402.

40 Seegobin RD, Wilmshurst TH, Johnston J, et al. I postoperative myocardial morbidity in patients wi nary artery disease undergoing major non-cardiac correlation with perioperative ischaemia. Can J A 1991; 38: 1012-22.

41 Willms $D$, Shure $D$. Pulmonary edema due to upp way obstruction in adults. Chest 1988; 94: 1090-:

42 Dexter $F$, Tinker $J H$. Analysis of strategies to dec postanesthesia care unit costs. Anesthesiology 19 ! 94-101.

43 Dexter $F$, Tinker JH. The cost efficacy of hypoth eliminating adverse anestheticjoutcomes from hig but neither low- nor moderate-risk, surgical opera Anesth Analg 1995; 81: 939-44.

44 DiBendetto RJ, Graves SA, Gravenstein N, Konic Pulse oximetry monitoring can change routine ox supplementation practices in the postanesthesia $\mathrm{c}$ Anesth Analg 1994; 78: 365-8.

45 Gift AG, Stanik J, Karpenick J, Whitmore K, Bolg Oxygen saturation in postoperative patients at lov hypoxemia: is oxygen therapy needed? Anesth A 1995; 80: 368-72.

46 Cooper JB, Cullen DJ, Nemeskai $R$, et al. Effects mation feedback and pulse oximetry on the incids anesthesia complications. Anesthesiology 1987; $C$ 686-94.

47 Zelcer J, Wells DG. Anaesthetic-related recovery complications. Anaesth Intensive Care 1987; 15:

48 Cohen MM, Duncan PG, Pope WDB, Wolkenstei survey of 112,000 anaesthetics at one teaching hc (1975-1983). Can J Anaesth 1986; 33: 22-31.

49 Hines RL, Barash PG, Watrous G, $O^{\prime}$ Connor $T$. cations occurring in the postanesthesia care unit: Anesth Analg 1992; 74: 503-9.

50 Van der Walt JH, Webb RK, Osborne GA, Morga Mackay $P$. The Australian Incident Monitoring S Recovery room incidents in the first 2000 inciden Anaesth Intensive Care 1993; 21: 650-2. 


\section{Les soins de la période postanesthésique}

\section{Objectifs}

Cette discussion comportera quatre sections. D'abord l'histoire de l'unité de soins postanesthésiques (Post Anaesthesia Care Unit ou PACU) sera exposée brièvement pour faire mieux comprendre pourquoi elle est nécessaire et comment elle a évolué. Deuxièmement, les directives actuelles et certaines suggestions portant sur la gérance et la prestation des soins dans les unités de soins postanesthésiques seront évaluées. Le troisième partie permettra de jeter un regard sur les études épidémiologiques qui ont permis d'identifier les problèmes les plus fréquents et les stratégies appliquées à la prévention et au traitement de ces problémes seront exquissées. Comme il est improbable que les unités de soins postanesthésiques actuelles puissent échapper aux coupures bugétaires, cet exposé se terminera par une brève discussion des tendances futures et des changements éventuels à apporter à l'organisation et la gestion des unités de soins postanesthésiques.

\section{Historique: pourquoi des unités de soins postanesthésiques?}

Le concept de la salle de réveil n'a pas toujours fait partie de celui de l'hôpital. La première description d'une salle de réveil date de 1801 et nous vient du Newcastle Infirmary au Royaume-Uni. Ce n'est toutefois que 70 ans plus tard que s'ouvrit au Massachusetts. General Hospital une véritable salle de réveil.'

Ce n'est réellement qu'après la deuxième guerre mondiale que les salles de réveil ont fait leur apparition sur les plans des nouveaux hôpitaux. ${ }^{2}$ Les salles de réveil ont été établies pour que le patient puisse reprendre conscience en toute sécurité et qu'il puisse s'y réchauffer. Ces salles écartaient aussi les autres patients des désagréments causés par les bruits et la vue des patients qui vomissaient! L'importance de la salle de réveil ne fut cependant reconnue qu'en 1947 dans un article publié dans le Journal of the American Medical Association. ${ }^{3}$ Des décès périopératoires associés à l'obstruction des voies respiratoires y étaient rapportés et la nécessité d'une salle réservée aux soins postanesthésiques était fortement soulignée.

Portant sur une période aussi récente que celle de 1978 à 1982, une étude de Tiret jugeait qu'il survenait une complication anesthésique majeure sur 700 anesthésies et que parmi les cas dont l'issue était le décès ou le coma, environ la moitié était associée à une complication postanesthésique. ${ }^{4}$ La dépression respiratoire était fatale dans $70 \%$ des cas quand elle survenait à l'étage comparativement à $29 \%$ au bloc opératoire, en salle de réveil ou à l'unité de soins intensifs. Les auteurs concluaient que le pronostic avait un rapport direct avec l'accès à une salle de réveil.

Le rôle de la salle de réveil évolue constamment. Les unités de soins intensifs possédant des capacités de ventilation mécanique postopératoire sont souvent inadéquates. Cette lacune justifiait la création d'unités de soins postanesthésiques pour les cas complexes qui doivent être traités intensivement pour de courtes durées. D'autre part, le virage ambulatoire actuel élargit le rôle des unités de soins postanesthésiques incluant la prise en charge de patients qui seront libérés directement vers la maison. L'éventail des cas admis à l'unité de soins postanesthésiques dépend évidemment de la vocation de chaque hôpital.

\section{Standards actuels}

Les directives de la Société Canadienne des Anesthésistes mises à jour en 1995, comprenaient une section spécifique sur la période postanesthésique. ${ }^{5}$ Ces recommandations énoncaient que dans tout hôpital où se pratiquait l'anesthésie devait posséder une salle des réveil. Il était aussi recommanndé que le département d'anesthésie prenne charge de l'administration de cette salle et spécifiait, en outre, que les soins ne devraient être délégués au personnel infirmier de la salle de réveil qu'après la vérification par l'anesthésiste le patient était stable et pris en charge par le personnel infirmier.

Les patients pouvaient être libérés des unités de soins postanesthésiques soit par un anesthésiste soit par son délégué en accord avec la politique de l'hôpital. Les directives reglémentaient aussi l'équipement nécessaire à la réanimation, les respirateurs, les sources d'oxygène, les dispositifs d'aspiration et l'oxymétrie de pouls. Les directives mentionnaient que des dossiers pertinents, incluant un régistre des complications devaient être tenus sur chacun des patients. Au Canada, les règlements canadiens ont rendu l'oxymétrie de pouls obligatoire le premier juillet 1995.

Des directives identiques ont été approuvées par l'American Society of Anesthesiologists en $1994 .^{6}$ De plus, les directives américaines proposaient l'utilisation 
pour chaque patient de scores d'évaluation à l'admission et à intervalles appropriés jusqu'au congé. ${ }^{7}$ Ces règles stipulent aussi qu'un médecin compétent pour traiter les complications et procurer la réanimation cardiorespiratoire aux patient soit disponible en tout temps.

\section{Pourquoi les unités de soins postanesthésiques sont-elles importantes?}

Certains participants au débat sur les résultats véritables de l'anesthésie suggèrent que les incidents survenant aux unités de soins postanesthésiques ne sont en réalité que des étapes intermédiaires. Les chercheurs ont suggéré récemment qu'il était non seulement essentiel d'identifier les incidents rapidement (par ex., les problèmes survenant aux unités de soins postanesthésiques) mais qu'il était aussi impératif d'identifier ceux qui ont un impact sur la morbidité à long terme et sur les coûts hospitaliers. ${ }^{8.9}$ Des études portant sur les problémes respiratoires rares mais graves survenant au unités de soins postanesthésiques portent à croire que ces problèmes sont associés à une augmentation de la morbidité postopératoire. Par ailleurs, la détection d'incidents fréquents (par ex., l'hypoxémie détectée par oxymétrie de pouls) n'a pas permis de diminuer l'incidence des complications postopératoires majeures. ${ }^{10}$

D'autre part, lorsqu'un patient se plaint d'une douleur très intense à l'unité des soins postanesthésiques, il est plus susceptible de souffrir d'avantage après son départ de l'unité." De la même façon, les nausées et vomissements ont été associés à une augmentation du séjour aux unités de soins postanesthésiques et d'une réadmission imprévue à l'hôpital, avec le résultat que les coûts de ce secteur hospitalier augmentent. Lorsqu'on considère l'impact du séjour aux unités de soins postanesthésiques sur la morbidité à long terme, l'évaluation des soins peut nécessiter l'introduction de nouveaux critères (par ex., la satisfaction du patient et le délai nécessaire pour le retour aux activités quotidiennes normales).

\section{Type et fréquence des complications survenant aux} unités de soins postanesthésiques

Malgré les progrés réalisés dans les domaines du monitorage et de la gestion de l'anesthésie, plusieurs études ont rapporté une incidence d'incidents élevée (Tableau I). Ces études illustrent que le pourcentage des incidents aux unités de soins postanesthésiques depend du type d'incidents inclus dans l'étude et de la définition de ces incidents.

A l'hôpital St.Micheal de Toronto, nous avons étudié les problèmes les plus fréquents a l'unité des soins postanesthésiques avec des définitions beaucoup plus rigoureuses qui tenaient compte des écarts des limites physiologiques normales et d' interventions spécifiques
TABLEAU I Fréquence des problèmes rencontrés aux unités de soins postanesthésiques

- Incidents graves (1986 - USA $)^{46}-7 \%$

- Incidents en rapport avec l'anesthésie (1985 - Autralie) ${ }^{47}-30 \%$

- Complications graves $(1975 \text { - } 1983 \text { - Canada })^{48}-5 \%$

- Relevé des complications (1986 - 1989 - USA $)^{49}-24 \%$

- Incidents graves en rapport avec l'anesthésie (1987-1992 Australie $)^{50}(6 \%$ survenus dans les unités de soins postanesthésiques)

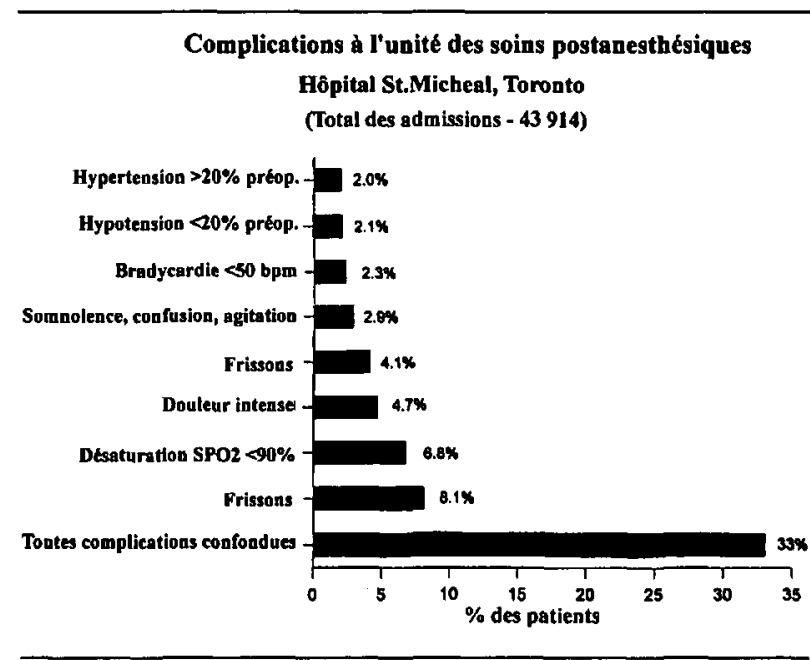

FIGURE

(Figure). Entre 1991 et 1994, 43914 patients consécutifs ont été admis à unité des soins postanesthésiques. Trente-trois pour cent de ces patients ont eu des problèmes de différentes natures, les plus communs étant les nausées et les vomissements, la désaturation, la douleur intense, la confusion et l'agitation, la bradycardie, l'hypotension et l'hypertension.

Plusieurs des problèmes spécifiques aux unités de soins postanesthésiques seront maintenant revus en tenant compte de la fréquence, de l'étiologie, de la prévention et du traitement. En général, ces remarques peuvent s'appliquer à tous les patients qui sont habituellement admis aux unités de soins postanesthésiques.

\section{Les nausées et les vomissements}

Malgré des décennies de recherches, les nausées et vomissements demeurent le problème le plus fréquent observé aux unités de soins postanesthésiques. Ceci ne peut représenter que la pointe de l'iceberg étant donné qu'ils surviennent encore plus souvent et plus tard à la période postopératoire. Les facteurs associés à l'augmentation de la fréquence de nausées et des vomissements sont notés au Tableau II. ${ }^{12}$

Plusieurs études contrôlées et aléatoires se sont at- 
TABLEAU II Facteurs qui augmentent le risque de nausées et vomissements

- Le sexe féminin

- Le jeune âge

- Les antécédents de nausées et vomissements périopératoires

- Les non fumeurs

- Les interventions abdominales, laparoscopiques et les corrections de strabisme

- Les morphiniques en postopératoire

tardées aux différents traitements préventifs des nausées et des vomissements. On a montré que le propofol utilisé pour l'induction de l'anesthésie et en perfusion continue pour le maintien, diminuait les nausées et les vomissements après la chirurgie ambulatoire. ${ }^{13}$ L'administration de dropéridol à différentes doses diminue aussi l'incidence des nausées et vomissements; par contre, en ce qui concerne la métoclopramide dont la durée d'action est plus courte, les résultats ne sont pas concluants. ${ }^{14}$ Les plus récents inhibiteurs de la sérotonine coûtent plus cher mais produisent des résultats identiques sinon supérieurs au dropéridol. ${ }^{15}$ Les inhibiteurs de la sérotonine semblent avoir peu d'effets secondaires mais, dans notre hôpital, nous n'en avons pas trouvé plus qu'avec le dropéridol (Cohen, Rose, Yee, sous presse).

Malgré leur utilisation habituelle pendant plusieurs années, l'efficacité des antiémétiques de sauvetage a été peu étudiée. Les médicaments utilisés habituellement dont l'efficacité varie comprennent des antihistaminiques, (le dimenhydrinate - Gravol ${ }^{\circledR}$ et la diphenhydramine - Benadryl ${ }^{\circledR}$ ), des phénothiazines (perphénazine - Trilafon ${ }^{\circledR}$ et prochlorpérazine - Stemetil $\left.{ }^{\circledR}\right)$, des benzamides (métoclopramide - Maxeran ${ }^{\circledR}$ ), des butyrophénones (dropéridol - Inapsine ${ }^{\circledR}$ ) et un alphastimulant (l'éphédrine).

Malheureusement, mêmes les agents thérapeutiques et prophylactiques qui diminuent l'incidence des nausées et des vomissements comparativement à un placebo ne réduisent que rarement à plus de $50 \%$ cette incidence. Les nausées et les vomissements postopératoires demeurent un petit problème qui refuse de disparaître et représente une source d'insatisfaction et une cause de délai pour le congé de la salle de réveil.

\section{Problèmes respiratoires}

Pour l'anesthésiste, les complications respiratoires de la période postanesthésique sont un sujet majeur de préoccupation. Heureusement, la fréquence des complications respiratoires graves est faible. Dans l'étude de 1981 de Beard, une complication respiratoire ne survenait que 44 fois sur 2293 cas d'anesthésie générale (1.9\%).

Notre étude réalisée au St. Micheal Hospital dix ans
TABLEAU III Facteurs qui augmentent le risque de problèmes respiratoires

\author{
- L'obésité \\ - L'âge avancé \\ - La chirurgie abdomiale \\ - Les interventions urgentes \\ - Les morphiniques pré- et postoperatoires \\ - Les relaxants musculaires \\ - L'obstruction des voies aériennes au réveil
}

plus tard a montré que des incidents respiratoires graves étaient survenus chez $1,3 \%$ des 24157 patients admis à l'unité des soins postanesthésiques après une anesthésie générale. Plus des deux tiers de ces incidents étaient associés à la désaturation de l'hémoglobine $<90 \%$. Ces incidents potentiellement dangereux ont été traités par l'insertion d'une canule nasale ou orale $(59,7 \%)$ et par des manipulations des voies aériennes $(47,6 \%)$. Vingt-deux patients seulement ont dû être intubés d'urgence.

Certains facteurs propres au patient et à la chirurgie, ainsi que d'autres spécifiques à la gestion de l'anesthésie peuvent augmenter le risque de problèmes respiratoires aux unités de soins postanesthésiques (Tableau III). Par ordre de fréquence décroissante, les incidents respiratoires observés aux unités de soins postanesthésiques sont l'hypoxémie, l'hypoventilation, l'obstruction des voies aériennes, le bronchospasme, le laryngospasme, l'aspiration bronchique et le pneumothorax.

Des épisodes d'hypoxémie $\left(\mathrm{SpO}_{2} \leq 90 \%\right)$ ont été notés chez plus de $55 \%$ des patients. ${ }^{18}$ Plusieurs de ces patients recevaient un supplément d'oxygène et $95 \%$ de ces épisodes n'ont pas été reconnus par le personnel. A l'unité des soins postanesthésiques, l'étiologie de l'hypoxémie la plus souvent rencontrée est la perturbation du rapport $V / Q$ et se voit surtout chez les patients dont la fonction pulmonaire était đéjà médiocre avant l'intervention (par ex., une $\mathrm{SPO}_{2}$ diminuée).

A l'unité de soins postanesthésiques, l'hypoventilation se manifeste par une fréquence respiratoire lente ou

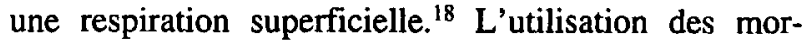
phiniques est associée à une diminution de l'effort respiratoire (fréquence respoiratoire diminuée). ${ }^{19}$ Il est facile de traiter l'hypoventilation induite par un morphinique avec un antagoniste mais sa durée d'action peut être plus courte que le morphinique à l'origine du problème. $\mathrm{Si}$ on considère l'étiologie de l'hypoxémie et de l'hypoventilation, il est important de noter qu'une altération du niveau de conscience à l'arrivée à l'unité de soins postanesthésiques constitue un facteur de risque important. ${ }^{20}$ Initialement, les signes et symptômes de l'hypoxémie et de l'hypoventilation peuvent passer ina- 
perçus. L'obstruction des voies aériennes secondaire à l'inconscience, les effets résiduels des relaxants musculaires et un saignement chirurgical au niveau des voies respiratoires nécessitent un diagnostic rapide.

La pneumonie d'aspiration est extrêmement rare. Un survol récent en a identifié 67 cas sur 215488 anesthésies générales. ${ }^{21}$ Heureusement, $64 \%$ de ces patients ne présentaient aucune anomalie clinique, radiologique ou paraclinique; en outre, aucun des patients asymptomatiques n'a développé de séquelles respiratoires. Les auteurs pensent que si les patients qui présentent des signes cliniques d'aspiration ne développent pas de symptômes en deçà de deux heures de la chirurgie, la possibilité de séquelles respiratoires subséquentes est pratiquement nulle.

Le type d'intervention chirurgicale (abdominale supérieure, néphrectomie et néphrostomie percutanée) peut être à l'origine d'un pneumothorax. En cas de pneumothorax, on recommande d'insérer des drains thoraciques aux patients qui auront besoin de ventilation mécanique; pour les autres, l'usage des drains thoraciques devrait être limité à ceux qui sont symptomatiques ou dont le pneumothorax est de $20 \%$ et plus. La prévention des problèmes respiratoires nécessite 1'identification précoce du patient à risque, la ventilation mécanique postopératoire planifiée, l'abandon des agents qui dépriment le niveau de conscience, le soulagement de la douleur à la période postopératoire et un monitorage étroit de tous les patients après une anesthésie générale dans une unité de soins où le personnel est prêt à intervenir rapidement.

\section{La douleur}

Après une chirurgie majeure, tous les patients souffrent, mais l'intensité de la douleur varie considérablement. Evaluer la douleur est aussi difficile que la prévenir et la traiter. La douleur est évaluée avec différentes méthodes dont l'attribution de scores sur une échelle visuelle analogique (EVA: 0 = aucune, maximum = la pire douleur imaginable) avec les mouvements et au repos; des échelles verbales simples (aucune, légère, modérée, intense et très intense); la fréquence des démandes et la quantité de morphinique administrée; et les symptômes physiques associés à la douleur intense (par ex., les gémissements ou l'état de crispation). En présence de sédation et de confusion, la mesure de la douleur est inconstante. Plusieurs études récentes portant sur les méthodes d'allégement ne tiennent pas compte du séjour du patient à unité de soins postanesthésiques mais se concentrent plutôt sur les périodes subséquentes au départ de l'unité.

Au cours d'une étude, on a mesuré les scores sur EVA de patients soumis à une chirurgie abdominale au
TABLEAU IV Stratégies permettant de soulager la douleur postopératoire précoce

\begin{tabular}{ll}
\hline Les AINS & Préopératoires, peropératoires \\
L'anesthésie locale & $\begin{array}{l}\text { Infiltration de la plaie } \\
\text { Injection intraarticulaire } \\
\text { Bloc nerveux } \\
\text { Épidurale/rachianesthésie }\end{array}$ \\
& $\begin{array}{l}\text { Intraveineux (courte vs longue durée) } \\
\text { Épiduraux/intrarachidiens }\end{array}$
\end{tabular}

Combinées

Chrónologie préventive

moment de l'admission à l'unité de soins postanesthésiques. ${ }^{22}$ Les scores $(0-10)$ étaient élevés $(>6)$ et étaient en relation avec la gestion peropératoire. Nos propres données au St. Micheal Hospital suggèrent aussi que la fréquence de la douleur postopératoire initiale est élevée. ${ }^{23}$ Notre étude de 5000 patients à haut risque admis à l'unité de soins postanesthésiques (après une chirurgie majeure non urgente sous anesthésie générale) a montré que la fréquence de douleurs très intenses définies par la présence de gémissements ou de crispations, ou encore par la nécessité de soins infirmiers axés surtout sur le contrôle de la douleur, était de 14,8\%. La fréquence des douleurs intenses varie avec l'âge, l'utilisation d'analgésie préopératoire, de l'intervention et des méthodes utilisées pour diminuer la douleur postopératoire. (Tableau IV).

Récemment, on innovait dans le domaine de la gestion de la douleur postopératoire en administrant des AINS et des anesthésiques locaux, mais l'efficacité de cette approche en pratique courante n'est pas évidente. Comparativement à un placebo, le naproxen oral administré à des patients ambulatoires en bonne santé opérés pour une chirurgie arthroscopique ou une ligature tubaire par laparoscopie diminue les scores sur l'EVA à la première et à la deuxième heure. ${ }^{24,25}$ L'indométhacine diminue aussi les scores sur l'EVA mesurés 1.5 et 60 min après l'admission à l'unité de soins postanesthésiques de femmes en bonne santé opérées pour une chirurgie du sein et pour une chirurgie gynécologique. ${ }^{26}$ Cependant, des femmes opérées pour une hystérectomie abdominale à qui on avait administré du kétorolac pendant l'intervention, ont eu besoin de la même quantité de morphiniques à l'unité de soins postanesthésiques que dans le groupe placebo. ${ }^{27}$ Le coût du kétorolac et l'administration d'indométhacine par voie rectale en limite l'utilisation en pratique courante.

Des études ont démontré l'efficacité des anesthésiques locaux pour diminuer la douleur postopératoire 
TABLEAU V Etiologie de la somnolence, de la confusion et de l'agitation

- L'áge avancé

- La confusion/désorientation préopératoire

- L'alcoolisme

- Les anticholinergiques, benzodiazépines, barbituriques peropératoires

- L'hypoxémie

- La distension vésicale

- La douleur aiguë

- L'hypovolémie

- Les déseiquilibres électrolytiques

initiale. Comparativement à un groupe placebo, les patients qui avaient subi une untervention chirurgicale abdominale avec infiltration de bupivacaïne au niveau du site opératoire avaient des scores d'EVA inférieurs à leur arrivée à l'unité de soins postanesthésiques et ont eu besoin de moins de morphine. ${ }^{22} \mathrm{La}$ bupivacaïne intra-articulaire diminue les scores mesurés sur l'EVA une et deux heures après la chirurgie comparativement à la morphine intraarticulaire et prolonge aussi le délai avant la première dose de morphine. ${ }^{28}$ Bien que les bénéfices à long terme des épidurales aux morphiniques avec ou sans anesthésiques locaux soient controversés, Jayr et al. ont montré qu'un mélange de bupivacaïne et de morphine perfusé en continu dans l'espace épidural diminuait considérablement les scores d'EVA au repos comparativement à la morphine sous-cutanée. D'autres études ont suggéré que des approches variées et préventives, chaque modalité agissant à un site différent avant que la douleur ne se manifeste, pourraient diminuer la douleur postopératoire.

La morphine intraveineuse ou intramusculaire a constitué depuis toujours le traitement fondamental de la douleur postopératoire précoce. L'analgésie autocontrôlée (PCA) mise en marche à l'unité de soins postanesthésiques après une dose de charge de morphine administrée par le personnel infirmier améliore la satisfaction du patient et diminue la douleur pendant la période postopératoire subséquente ${ }^{30}$; il reste à déterminer si la PCA est supérieure aux autres méthodes de contrôle de la douleur. Les bénéfices des analgésiques à courte durée d'action (fentanyl et alfentanil) et les nouveaux AINS n'ont pas fait l'objet d'études complètes au regard du traitement de la douleur aiguë. Après la chirurgie ambulatoire, les analgésiques oraux peuvent être suffisants. Les hôpitaux comme les patients ont adopté la PCA rapidement et universellement mais aucune des autres modalités n'a connu le même succès.

\section{Somnolence, confusion et agitation}

Ces problèmes représentent un continuum de la dépres- sion du SNC souvent difficile à définir et quantifier à l'unité de soins postanesthésiques. Les patients agités nécessitent des soins constants de la part du personnel infirmier. Avec le nombre croissant d'interventions chirurgicales effectuées sur des personnes âgées, ce problème est susceptible de s'accroître. Les facteurs étiologiques décrits dans des articles de revue récents sont énumérés au Tableau V. .1-34 $^{31}$

L'halopéridol 0,5-5 mg iv constitue le traitement de choix du délire aigu en salle de réveil malgré le petit nombre d'études aléatoires qui l'ont rapporté. ${ }^{35}$ Pour un traitement à court terme, le midazolam et le propofol peuvent être utilisés.

\section{Les anomalies cardiaques}

Les changements rapides de pression artérielle, de fréquence et de rythme cardiaques sont assez fréquents à l'unité de soins postanesthésiques. D'autre part, l'ischémie, l'oedème pulmonaire et l'arrêt cardiaque sont rares. Les affections préopératoires (maladie coronaire, hypertension, insuffisance cardiaque congestive) aussi bien que les facteurs chirurgicaux (chirurgie vasculaire, prolongée, urgente) présentent une corrélation étroite avec les complications cardiaques postopératoires. ${ }^{36} \mathrm{De}$ plus, il a été démontré que d'autres problèmes (détresse respiratoire, douleur intense, agitation, nausées et vomissements) ont une relation avec les complications cardiovasculaires. ${ }^{37}$ L'identification du patient à risque, le contrôle hémodynamique peropératoire avec remplissage veasculaire et la pharmacothérapie, et la prévention des autres problèmes connexes peuvent prévenir l'instabilité hémodynamique a l'unité de soins postanesthésiques. Certaines anomalies comme la bradycardie n'ont pas nécessairement besoin d'être traitées.

Deux problèmes peu fréquents, l'ischémie et l'oedème pulmonaire, méritent une attention particulière. Le diagnostic de l'ischémie myocardique postopératoire depend des moniteurs utilisés pour la déceler. Aucune épreuve de détection de l'ischémie myocardique sensible et spécifique n'est disponible présentement. Les indices énumérés par ordre de sensibilité décroissante sont les anomalies pariétales segmentaires diagnostiquées par échographie transoesophagienne ou thoracique, les altérations enzymatiques, le monitorage continu du segment ST, l'enregisterment intermittent de l'ECG à 12 dérivation et la douleur thoracique décrite par le patient. ${ }^{38}$ Une heure après une intervention, des altérations de l'onde $\mathrm{T}$ surviennent chez environ $20 \%$ des patients mais leur incidence ne varie pas, que le patient souffre ou non de maladie coronaire, ce qui porte à croire que les altérations de l'onde $\mathrm{T}$ constituent un pauvre outil diagnostique. ${ }^{39}$ Le Holter (deux dérivations) a une sensibilité faible pour la détection de l'is- 
chémie postopératoire précoce comparativement aux douze dérivations en série et aux épreuves des CKMB. ${ }^{40}$ Dans cette étude, aucun des patients ne s'est plaint de douleur thoracique même pendant les changements du segment ST. Tout au plus, nous devons extrapoler, à partir des données préopératoires qui identifient le patient à haut risque d'ischémie myocardique, que ces indices améliorent l'habileté du clinicien à reconnaître les épisodes d'ischémie myocardique additionnels. Ces patients auront besoin d'un monitorage plus agressif après leur départ de l'unité de soins postanesthésiques. Comme à la période préopératoire, il existe une forte chance que ces épisodes ischémiques demeurent silencieux.

A la période postopératoire initiale, l'oedème pulmonaire est rarement dû à une surcharge liquidienne excepté chez le patient dont la fonction myocardique est gravement altérée ou chez ceux ou celles qui ont reçu des perfusions hydriques exagérées (par ex., hystéroscopie et RTUP). L'oedème postopératoire précoce peut aussi survenir par obstruction des voies aériennes. ${ }^{41}$ L'étiologie de cet oedème pulmonaire non cardiogénique peut provenir de la pression pulmonaire négative transpulmonaire qui favorise la transudation du liquide capillaire pulmonaire vers l'espace alvéolaire. On a aussi émis l'hypothèse que l'oedème pourrait survenir à la suite de la relaxation de la pression négative transthoracique quand l'effet PEEP dû à l'expiration contre l'obstruction disparaît et que le liquide de l'espace alvéolaire dépasse la capacité de drainage des lymphatiques. Cette dernière théorie expliquerait pourquoi les patients developpe un oedème non cardiogénique immédiatement après la levée de l'obstruction des voies aériennes. La levée de l'obstruction et le traitement symptômatique (diurèse $\pm \mathrm{PEEP}$ ) corrigent l'oedème pulmonaire non cardiogénique.

\section{Nouveau problèmes et défis}

Les restrictions budgetaires du secteur des soins de santé n'ont pas épargné l'anesthésie. Tous les aspects des soins hospitaliers sont évalués en relation avec leur coûts incluant les unités de soins postanesthésiques.

Les budgets de fonctionnement des unités de soins postanesthésiques sont surtout accaparés par le personnel et pourraient dépasser $100 \$$ par patient (Rose - données non publiées). Il est possible que l'anesthésie réalisée avec des agents de courte durée d'action ou des agents qui préviennent ou mettent à l'abri des effets secondaires (par ex., nausées et vomissements) réduise les coût imputés en diminuant la durée du séjour.

Cependant, une analyse hypothétique récente par Dexter et al. estime que c'est en réorganisant les programmes opératoires en en fonction des admissions à l'unité qu'on pourrait diminuer le personnel infirmier, ce qui serait plus efficaces que toute autre tentative de réduction de la durée du séjour à l'unité. ${ }^{42}$ Une deuxième étude de Dexter et al. se penche sur les économies théoriques qui pourraient être réalisées si on éliminait les résultats défavorables de l'anesthésie. ${ }^{43}$ Hypothétiquement, l'économie serait de $0,5 \%$ après une transplantation rénale et de $1,8 \%$ après une prothèse totale de la hanche. Au cours de cette étude, les auteurs ont procédé en calculant le pourcentage de réduction des coûts en réduisant au niveau médian le coût des résultats défavorables. Cet article suggère qu'il pourrait être difficile de prouver que les stratégies qui diminuent les effets secondaires défavorables de l'anesthésie sont économiques tout en demeurant efficaces.

Il pourrait être nécessaire de revoir notre approche traditionnelle des unités de soins postanesthésiques. Deux articles récents ont suggéré qu'il était possible d'éliminer l'oxygénothérapie chez certains patients. ${ }^{44,45}$ Les unités de soins postanesthésiques qui associent la durée du séjour à la durée de l'anesthésie ou à la nature de l'intervention devraient réviser leurs protocoles. Des scores "d'aptitude » au départ semblables à ceux qui sont en vigueur en chirurgie peuvent réduire la durée du séjour aux unités de soins postanesthésiques. Eventuellement, des études nous aideront à identifier quels patients ont besoin ou bénéficient d'un séjour à l'unité de soins postanesthésiques. Il ne sera peut-être même plus nécessaire que tous les patients y séjournent. Ceci constituerait un revirement complet de la la tradition historique rapportée au début de cette présentation.

L'avenir de la recherche en anesthésie doit se tourner vers l'identification de stratégies orientées vers le patient (par ex., la diminution des complications et l'augmentation de la satisfaction) et produire une réduction générale des coût tant à la période périopératoirte qu'à l'unité de soins postanesthésiques.

\section{Références \\ (Voir page R121)}

